\title{
EFFECTS OF ETHANOL-DIESEL EMULSIONS ON THE PERFORMANCE, COMBUSTION AND EMISSION CHARACTERISTICS OF DI DIESEL ENGINE
}

\author{
${ }^{1}$ R. Parthasarathi, ${ }^{2}$ S. Gowri and ${ }^{3}$ C.G. Saravanan \\ ${ }^{1}$ Department of Mechanical Engineering, \\ Ganapathy Chettiar College of Engineering and Technology, Paramakudi, TamilNadu, India \\ ${ }^{2}$ Department of Mechanical Engineering, Anna University, Chennai, TamilNadu, India \\ ${ }^{3}$ Department of Mechanical Engineering, Annamalai University, Chidambaram, TamilNadu, India
}

Received 2013-08-21; Revised 2014-01-31; Accepted 2014-02-03

\begin{abstract}
The main objective of this study is to analyze the different ratio of emulsified fuels on the performance, emission and combustion characteristics of four stroke single cylinder kirloskar TV-I direct injection compression ignition engine and compared with diesel fuel under different engine loads with constant engine speed of $1500 \mathrm{rpm}$. Four kinds of test fuels were prepared namely $80 \%$ diesel, 10\% ethanol and 10\% surfactant (Identified as D80E10); 70\% diesel, 20\% ethanol and 10\% surfactant (denoted as D70 E20); 60\% diesel 30\% ethanol and 10\% surfactant (denoted as D60 E30); $50 \%$ diesel, $40 \%$ ethanol and $10 \%$ surfactant (denoted as D50 E40) by volume respectively. In this test, Benzal konium chloride is added as an emulsifier to the diesel-ethanol blend to prevent layer formation and to make it a homogeneous blend. At maximum brake power, the comparison of best emulsified fuel ratio with diesel fuel results showed improvement in brake thermal efficiency with decrease in specific fuel consumption and smoke. The $\mathrm{NO}_{\mathrm{X}}, \mathrm{HC}, \mathrm{CO}_{2}$, cylinder pressure and heat release rate for D50 E40 emulsions are higher when compared to diesel fuel.
\end{abstract}

Keywords: Diesel Engine, Ethanol, Surfactant, Performance, Combustion

\section{INTRODUCTION}

Diesel engines have higher thermal efficiency, specific power output with high fuel economy and are more efficient than gasoline engine. The major pollutants emitted from compression ignition engine are oxides of Nitrogen $\left(\mathrm{NO}_{\mathrm{x}}\right)$, Carbon monoxide (CO), Carbon dioxide $\left(\mathrm{CO}_{2}\right)$ and particulate matter. The scientists are confronted with the following new challenges; they are related with environmental hazards, fuel scarcity, energy demand and stringent emission norms. The above difficulties can easily be overcome by discovering more environmental friendly oxygenated fuels such as ethanol (Muralidharan and Govindarajan, 2011; Rajkumar and Govindarajan, 2011; Chockalingam et al., 2010).
Ethanol can be manufactured from simple agricultural materials like sugarcane, cassava, molasses, waste biomass materials, sorghum, corn, barley and sugar beets. It can also be manufactured from the agricultural crops, food and wood wastes. It is a renewable energy and can be derived chemically from ethane or ethylene and it has a simple molecular structure with carbon, hydrogen and oxygen atoms. It is a volatile and colorless liquid with a slight odor. It has high octane number when compared with other fuels like methanol, gasoline, natural gas and diesel. Knock resisting capacity is also more for ethanol (Cahyono and Bakar, 2011).

Ethanol cannot be easily mixed with diesel fuel because of the prevailing wax content, hydrocarboncomposition, water content and wide

Corresponding Author: R. Parthasarathi, Department of Mechanical Engineering, Ganapathy Chettiar College of Engineering and Technology, Paramakudi, TamilNadu, India Tel: +91 009976633539 
range of temperature of the diesel fuel. The problem of this occurrence can be solved by using emulsifier and co-solvent. There are three methods such as dual injection system, ethanol fumigation and emulsion process to accomplish the miscibility of diesel with ethanol (Lincy and Wang, 2003).

Ashok (2011) have studied the performance, emission and combustion characterictics of a constant speed CI engine on ethanol-diesel emulsion. They found that the increases the BTE but decreases the SFC, PM, $\mathrm{NO}_{\mathrm{X}}$ and EGT, at the maximum output load condition. Cahyono and Bakar (2011) studied the effects of ethanol addition in the combustion process during warm-ups and half open throttle on port injection gasoline engine using gasoline, ethanol 10 and $20 \%$ ethanol. He reported that the process of half open throttle will increase $\mathrm{CO}_{2}$ emissions and reduce $\mathrm{HC}$ and $\mathrm{CO}$, during warm-ups that while the increased $\mathrm{CO}$ but decreases $\mathrm{CO}_{2}$. Sayin (2010) researched the effect of ethanol-diesel (5 and $10 \%$ in volume) and methanol-diesel (5\% and $10 \%$ in volume) addition to diesel fuel on the performance and emissions of a diesel engine.The results showed that brake specific fuel consumption and emission of nitrogen oxides increased while BTE, smoke and carbon monoxide decreased with ethanol-diesel and methanol-diesel fuel blends. Prabhu et al. (2013) have conducted the experiment with neem oil and methyl ester of neem oil in a single cylinder, four stroke, direct injection diesel engine.They have reorted that maximum cylinder pressure and heat release rate are higher with the increase in biodiesel blends, also found that the carbon monoxide (CO) and smoke emissions were significantly lower, but Nitrogen Oxide $\left(\mathrm{NO}_{\mathrm{X}}\right)$ emissions are higher when operating on biodiesel-diesel blends. Jimenez et al. (2011) studied the physical and chemical physical properties of ethanol-diesel blends.Their results showed that the addition of ethanol leads to some changes in the above properties of emulsified fuel causing a significant reduction in the viscosity and to raise flash point and water content. Lei et al. (2012) studied the emulsification performance and stability of ethanol-diesel blends with single and mixed emulsifiers. They indicated that with a CLZ type emulsifier, the ethanol-diesel blend E10 can keep its physical stability at a wide range of temperature with improved brake thermal efficiency and reduced specific fuel consumption, also found that the smoke emissions was reduced and the $\mathrm{NO}_{\mathrm{X}}$ emission decreased slightly, while the total hydrocarbon emissions increased at heavy loads.

The main objective of this study was to study the performance, emission and combustion characteristics of different ratio of diesel-ethanol emulsions and to compare these results with diesel fuel in a single cylinder 4 stroke diesel engine at varying load conditions with constant engine Speed (1500 pm).

\section{MATERIALS AND METHODS}

Experiments were conducted on a single cylinder four stroke direct injection compression ignition engine as shown in Fig. 1 and the specification of the engine is given in Table 1. An eddy current dynamometer was used for loading the engine. The engine exhaust gas temperature was measured using chromel-alumel (ktype) thermo couple. An AVL di gas 444 analyzer was used to measure the amount of unburned Hydrocarbon (HC), oxides of Nitrogen $\left(\mathrm{NO}_{\mathrm{X}}\right)$, Carbon monoxide (CO) and Carbon dioxide $\left(\mathrm{CO}_{2}\right)$. The combustion chamber pressure was measured by a water cooled piezoelectric pressure transducer with a sensitivity of $16.11 \mathrm{pc} / \mathrm{bar}$, mounted on the engine cylinder head. The engine was started and allowed to warm up for about 30 min with diesel fuel to attain a normal working temperature. Experiments were started initially with diesel fuel and the results were obtained at 20, 40, 60, 80 and $100 \%$ load. Further the tests were repeated under above load conditions with different ratio of emulsified fuels at constant speed of $1500 \mathrm{rpm}$. Steady state performance and combustion readings were taken for three times. Finally the average value of the three readings was taken for further calculation. The properties of diesel, ethanol and best emulsified fuel ratio are summarized in Table 2.

Table 1. Engine specifications

\begin{tabular}{ll}
\hline Make & Kirloskar Tv-1 engine \\
\hline Type & Single cylinder, water cooled, \\
& 4 stroke diesel engine \\
Borexstroke & $87.5 \mathrm{~mm} \times 10 \mathrm{~mm}$ \\
Compression ratio & $17.5: 1$ \\
Rated brake power & $5.2 \mathrm{kw}$ \\
Speed & $1500 \mathrm{rpm}$ \\
Ignition system & Compression ignition \\
Ignition timing & $23^{\circ} \mathrm{bTDC}$ \\
Injection pressure & $20 \mathrm{kgf} / \mathrm{cm}^{2}$ \\
\hline
\end{tabular}

Table 2. Physical-chemical properties

\begin{tabular}{llll}
\hline Properties & Diesel & Ethanol & D50 E40 \\
\hline Density @ $15^{\circ} \mathrm{C}$ in $\mathrm{gm} / \mathrm{cc}$ & 0.8289 & 0.789 & 0.8184 \\
Specific gravity at $15^{\circ} \mathrm{C}$ & 0.81 & 0.796 & 0.826 \\
Kinematic viscosity $@ 40^{\circ} \mathrm{C}$ in cst & $3-4$ & 1.2 & 2.84 \\
Flash Point ${ }^{\circ} \mathrm{C}$ & 74 & 13 & 13 \\
Cetane number & 50 & $5-8$ & 46 \\
Calorific value $\mathrm{kj} / \mathrm{kg}$ & 42800 & 26,600 & 39132 \\
\hline
\end{tabular}




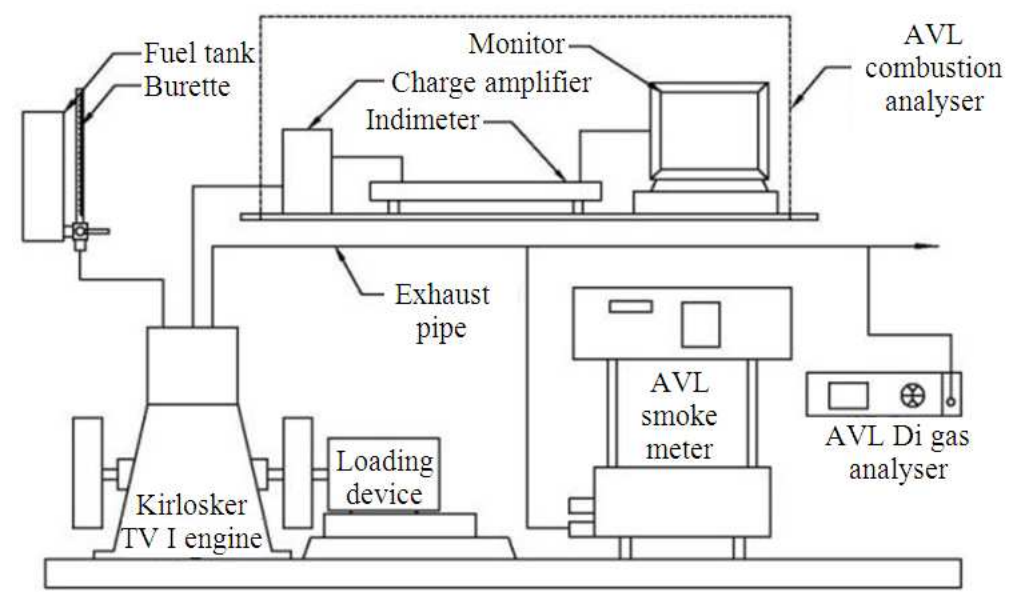

Fig. 1. Experimental setup

\section{RESULTS}

\subsection{Performance}

\subsubsection{Specific Fuel Consumption}

Figure 2 shows the variation of specific fuel consumption with brake power for different ratio of emulsified fuels and diesel fuel. It is observed that the SFC is found to decrease with increase in load and increase in the percentage of ethanol in diesel fuel. The specific fuel consumption is lower for the diesel-ethanol emulsion (D50E40) than for the diesel fuel. At maximum brake power, the minimum SFC is 0.260, 0.269, 0.278, 0.287 and $0.261 \mathrm{~kg} / \mathrm{kwhr}$ for D50E40, D80E10, D70E20, D60E30 and diesel respectively.

\subsubsection{Brake Thermal Efficiency}

Figure 3 shows the comparison between brake thermal efficiency and brake power of the engine. The brake thermal efficiency improved better for all emulsified fuels than diesel fuel. The maximum brake thermal efficiency of $35.7,34.1,32.8,31.1$ and $30 \%$ were observed for D50E40, D80E10, D70E20, D60E30 and diesel fuel respectively at maximum load. The increase in brake thermal efficiency is found to be $14.7 \%$ for D50E40 blend.

\subsection{Emission Analysis}

\subsubsection{Hydrocarbon (HC)}

Figure 4 shows the variation of hydrocarbon with brake power for diesel and various concentrations of emulsified fuels. The HC increases with increase in load for all fuels. It can be seen that the amount of $\mathrm{HC}$ emission is lower at part load and again increases at higher load conditions for all fuels. Compared to diesel and other blends, the HC emission is higher for D50E40 blend. At full load, the $\mathrm{HC}$ emission is $63 \mathrm{ppm}$ for D50E40 blend whereas $39 \mathrm{ppm}$ for diesel fuel.

\subsubsection{Oxides of Nitrogen $\left(\mathrm{NO}_{\mathrm{x}}\right)$}

Figure 5 shows the comparison of oxides of nitrogen $\left(\mathrm{NO}_{\mathrm{x}}\right)$ with respect to brake power for diesel and various proportions of emulsified fuel. The $\mathrm{NO}_{\mathrm{x}}$ emission for all the fuel was found to be minimum at lower load and again it increases when ethanol proportions in the blend is increased. At full load condition, higher $\mathrm{NO}_{\mathrm{x}}$ emission of $612 \mathrm{ppm}$ is observed for D50E40 blend as against 500 ppm for diesel.

\subsubsection{Smoke}

Figure 6 indicates the values of smoke against brake power for diesel and diesel-ethanol blends. It is observed that the increase in ethanol concentration, smoke density tends to decrease because of the less number of carbon atoms in ethanol as compared to diesel. The smoke density for the blend D50E40 is lower compared to diesel fuel at higher loads. The smoke density in the engine exhaust is found to be $39.4 \mathrm{HSU}$ for D50E40 blend whereas for neat diesel, it is 64.4 HSU.

\subsubsection{Carbon Dioxide $\left(\mathrm{CO}_{2}\right)$}

The variation of Carbon dioxide emission with brake power for diesel fuel and different ratio of emulsions is shown in Fig. 7. It can be seen that the D50E40 emulsion emitted higher amount of $\mathrm{CO}_{2}$ than diesel fuel. The maximum carbon dioxide emission is observed as $0.087 \%$ at maximum brake power of the engine. The reason may be attributed to the increasing amount of oxygen in the blend. 
R. Parthasarathi et al. / American Journal of Applied Sciences 11 (4): 592-600, 2014

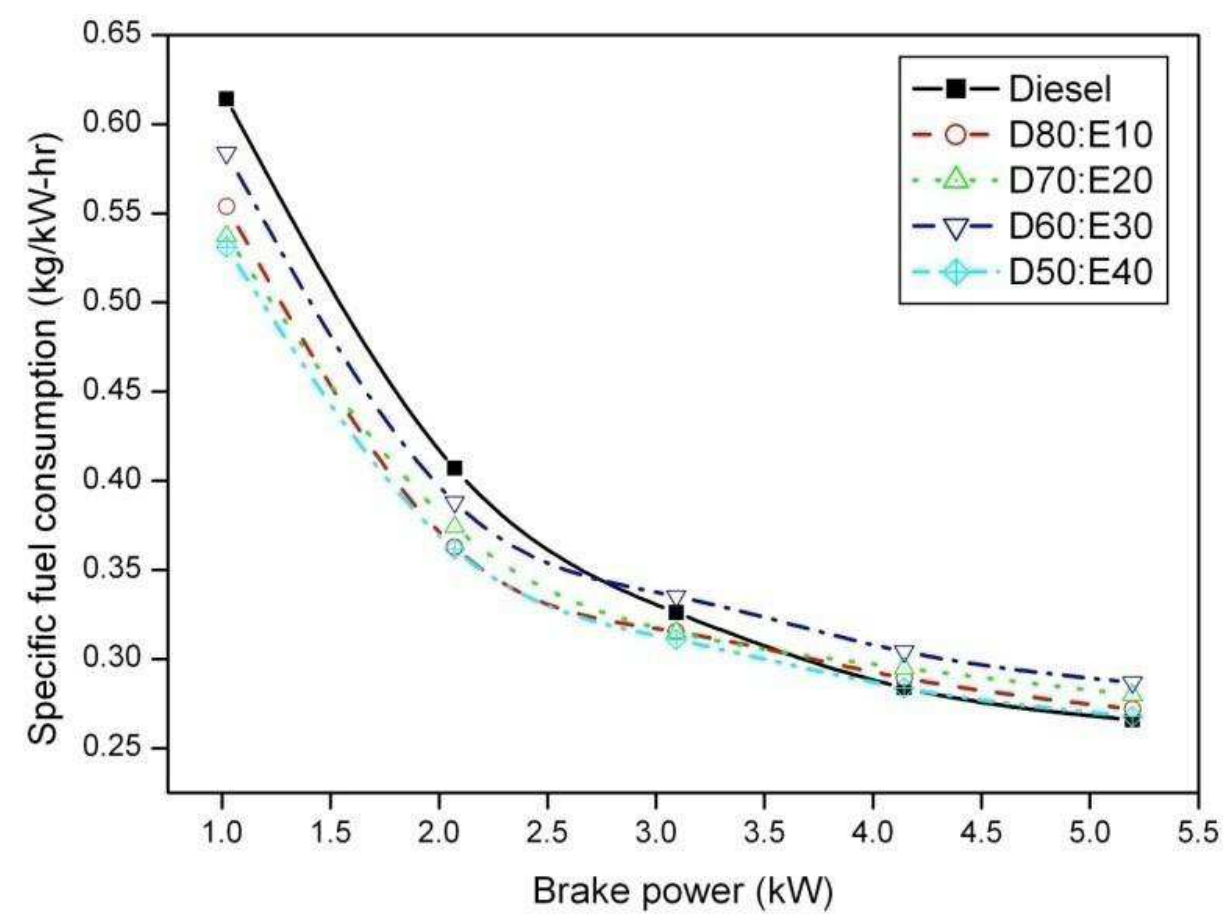

Fig. 2. Specific fuel consumption against brake power

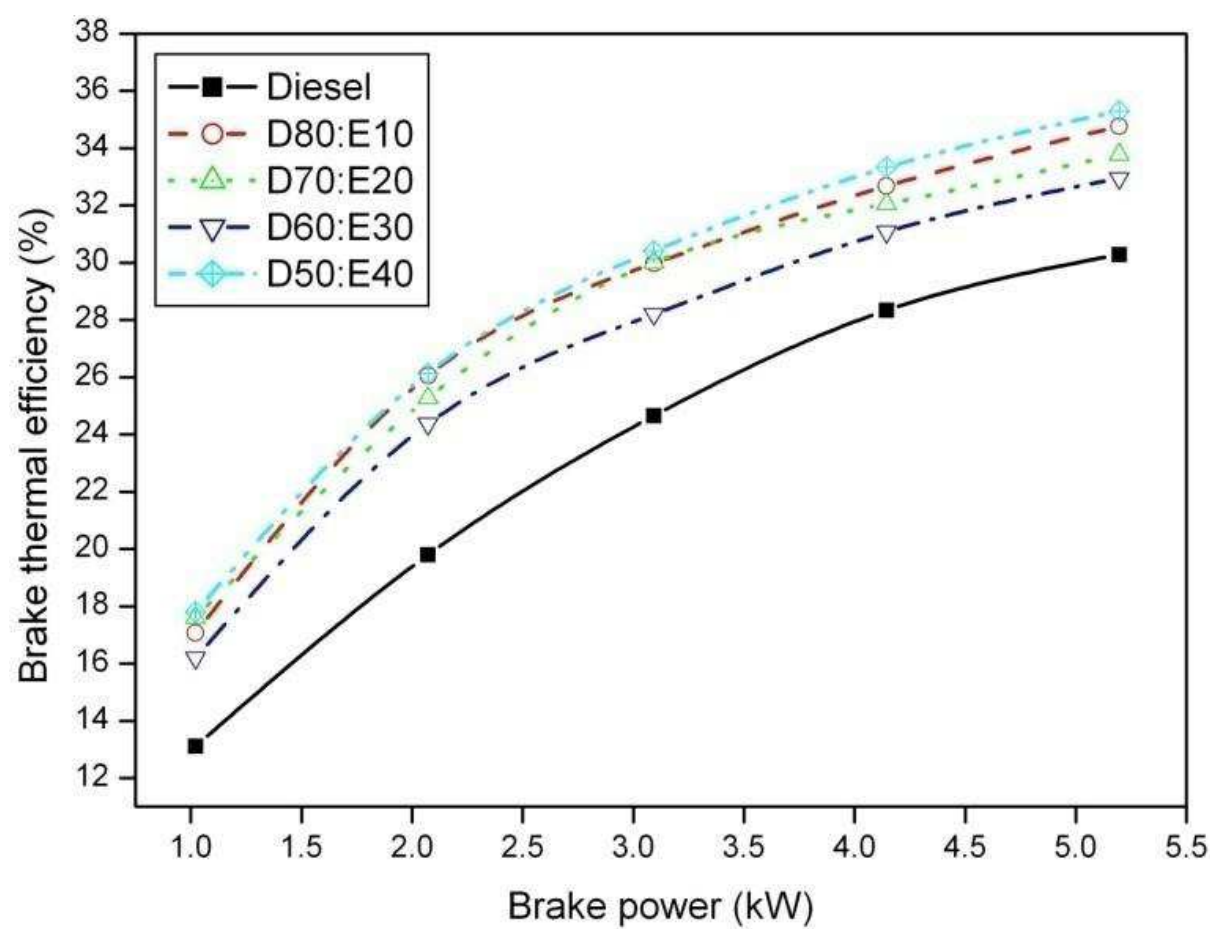

Fig. 3. Brake thermal efficiency against brake power 
R. Parthasarathi et al. / American Journal of Applied Sciences 11 (4): 592-600, 2014

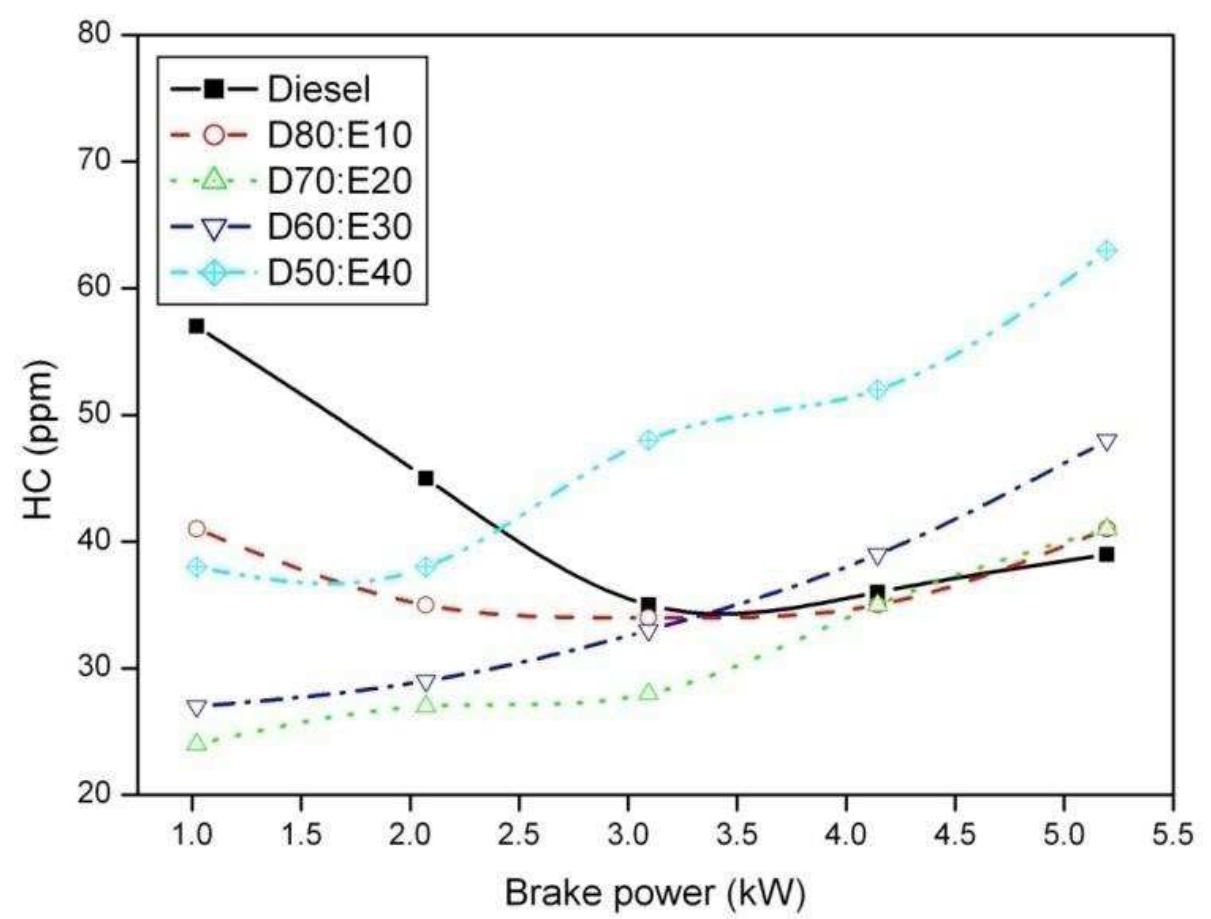

Fig. 4. Hydrocarbon against brake power

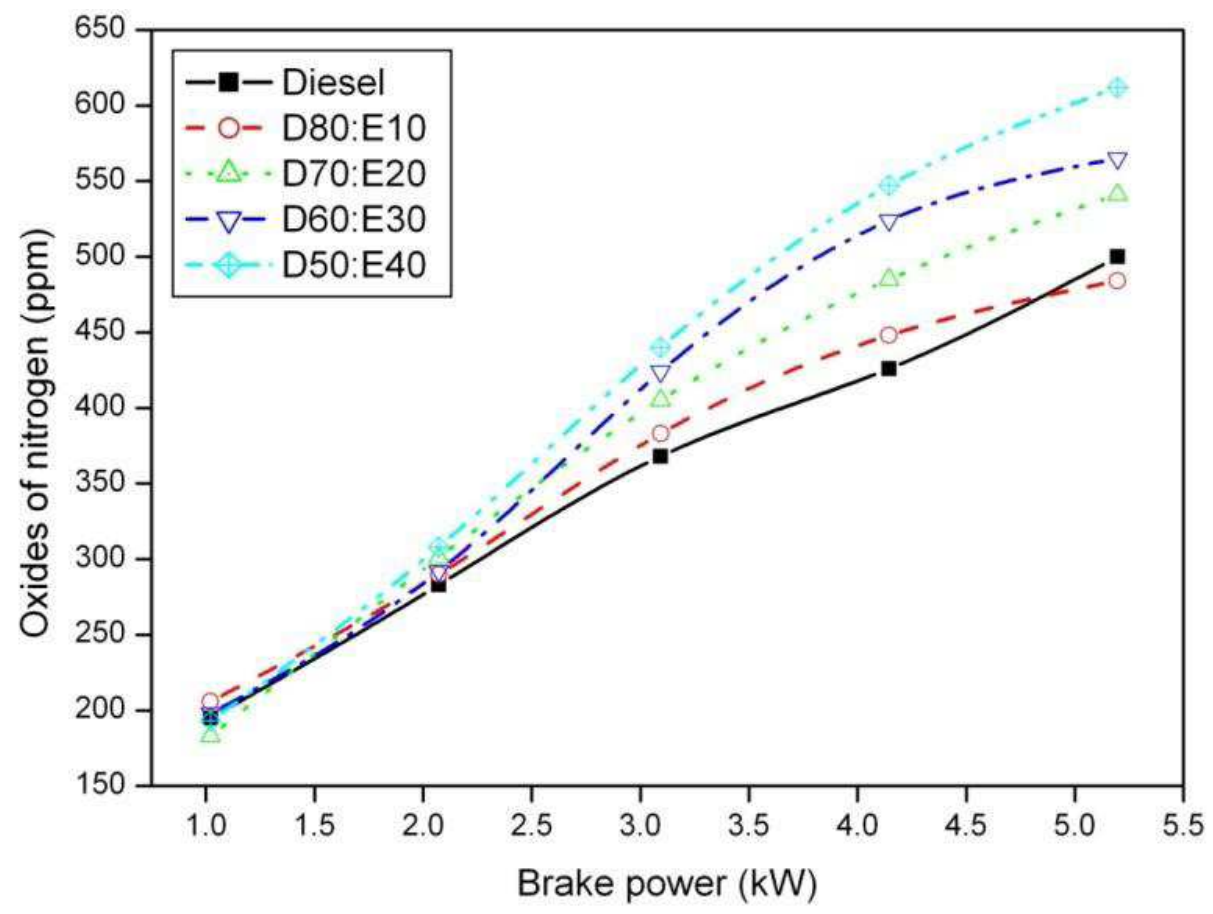

Fig. 5. Oxides of nitrogen against brake power 
R. Parthasarathi et al. / American Journal of Applied Sciences 11 (4): 592-600, 2014

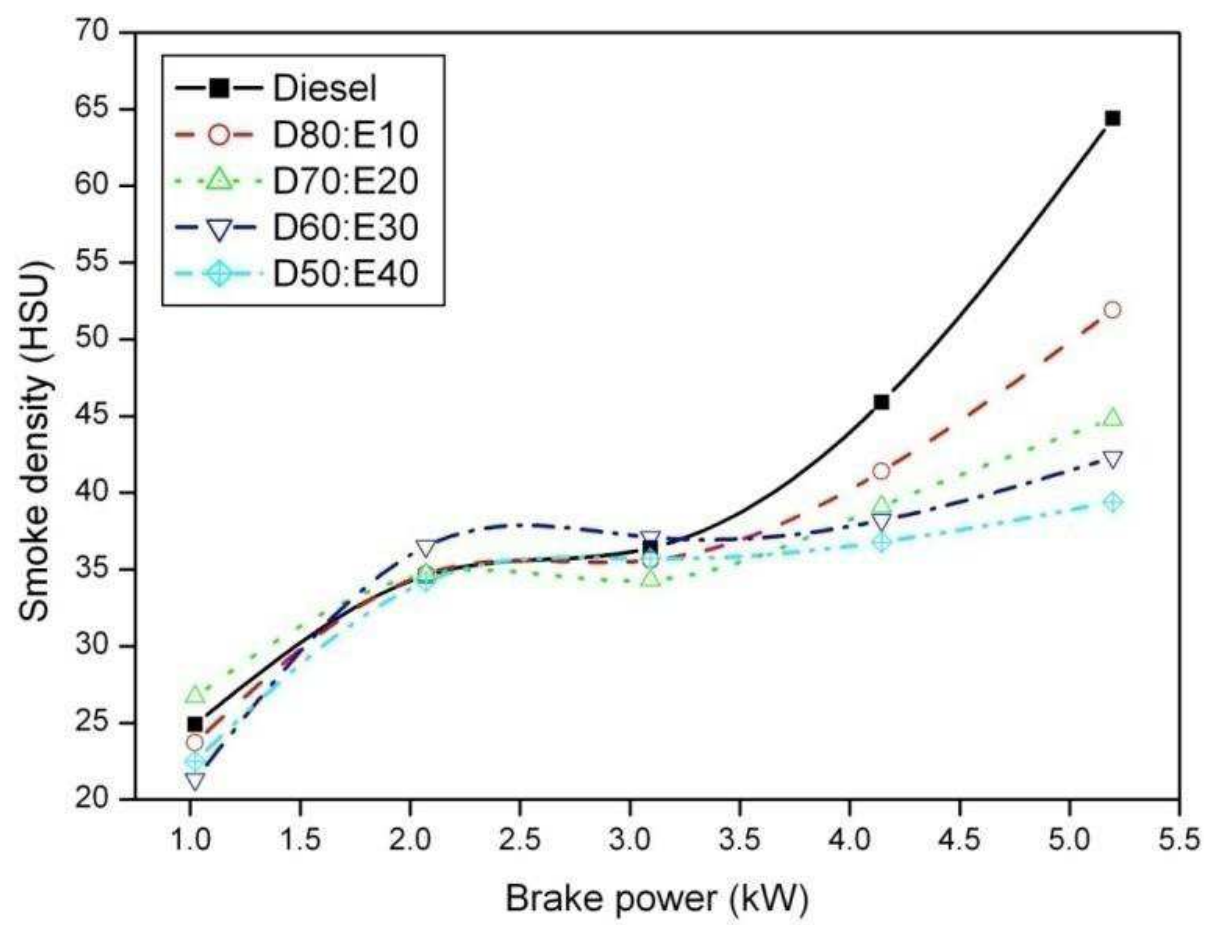

Fig. 6. Smoke against brake power

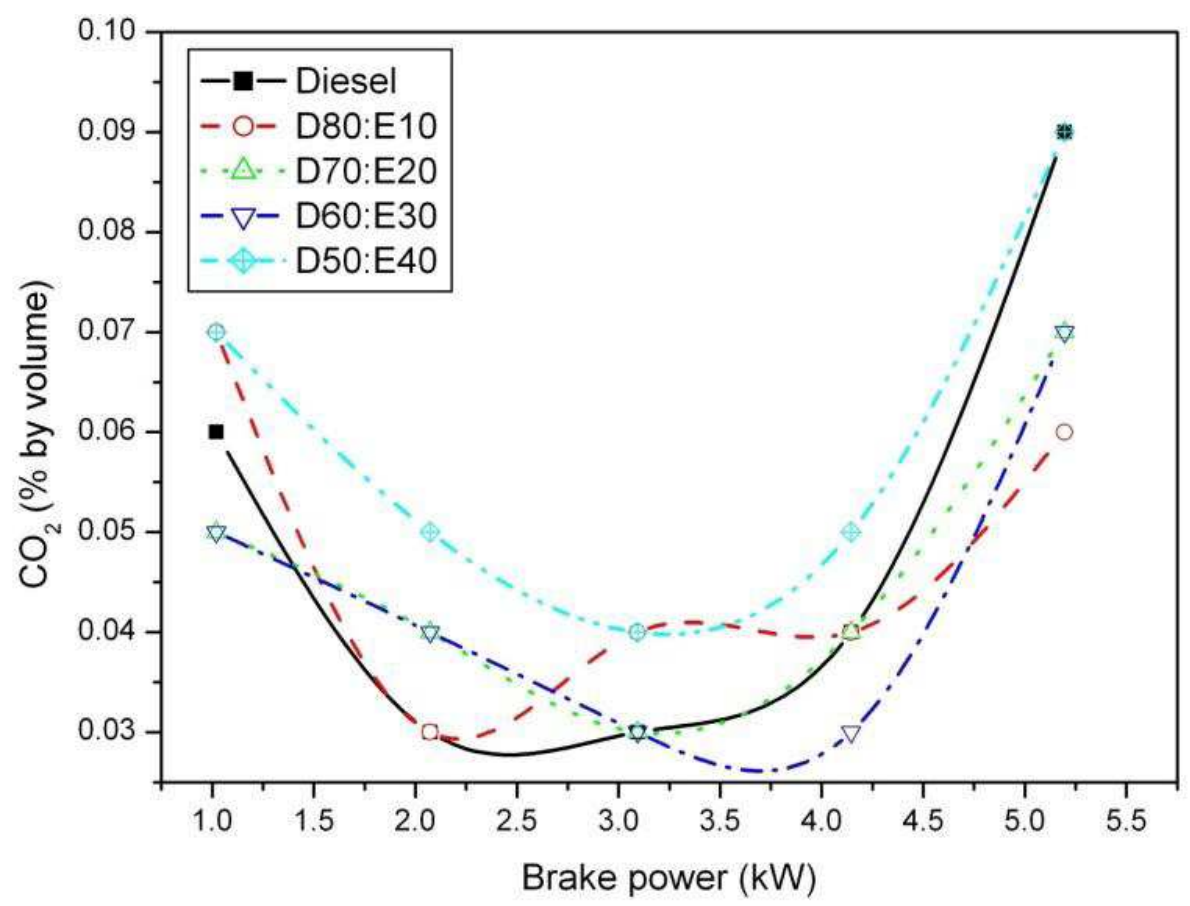

Fig. 7. Carbon dioxide against brake power 
R. Parthasarathi et al. / American Journal of Applied Sciences 11 (4): 592-600, 2014

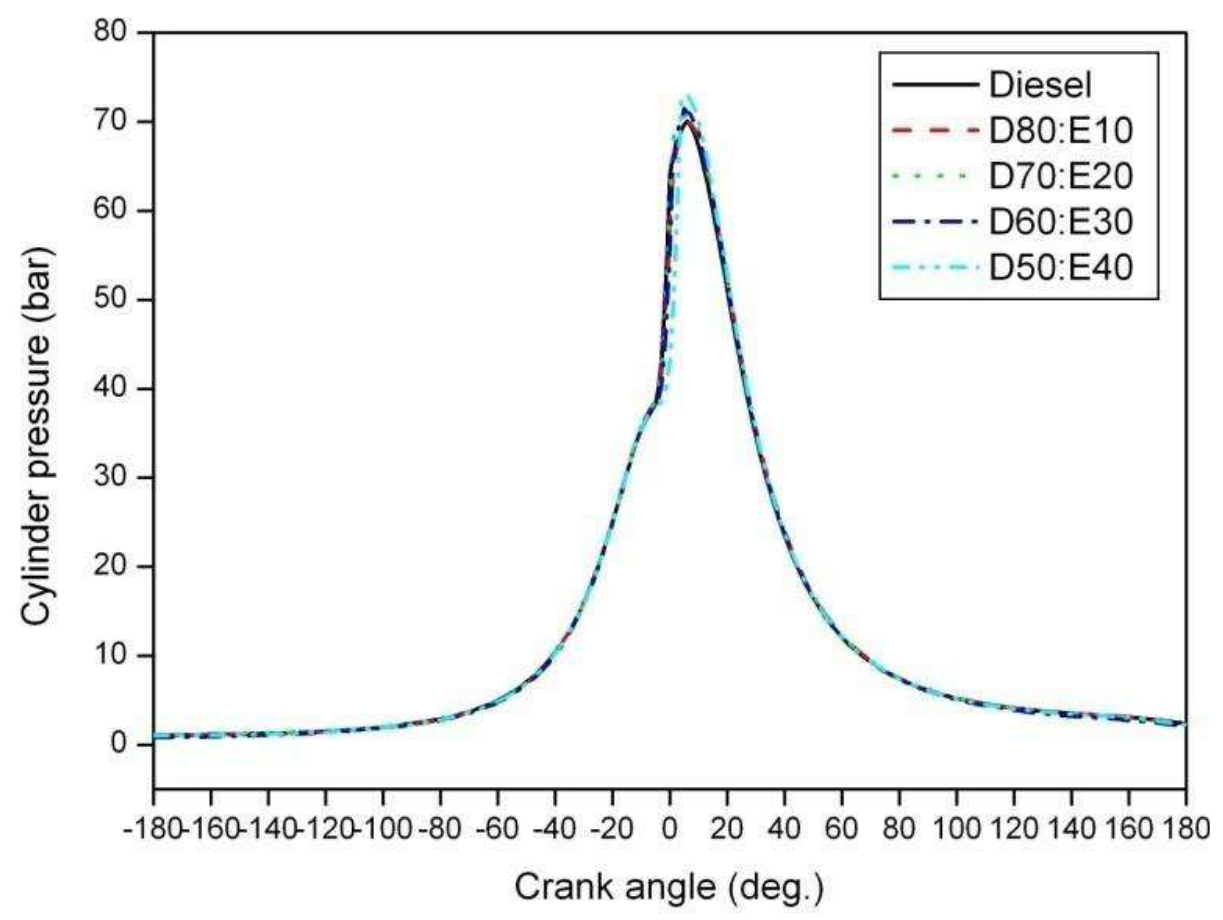

Fig. 8. Cylinder pressure against brake power

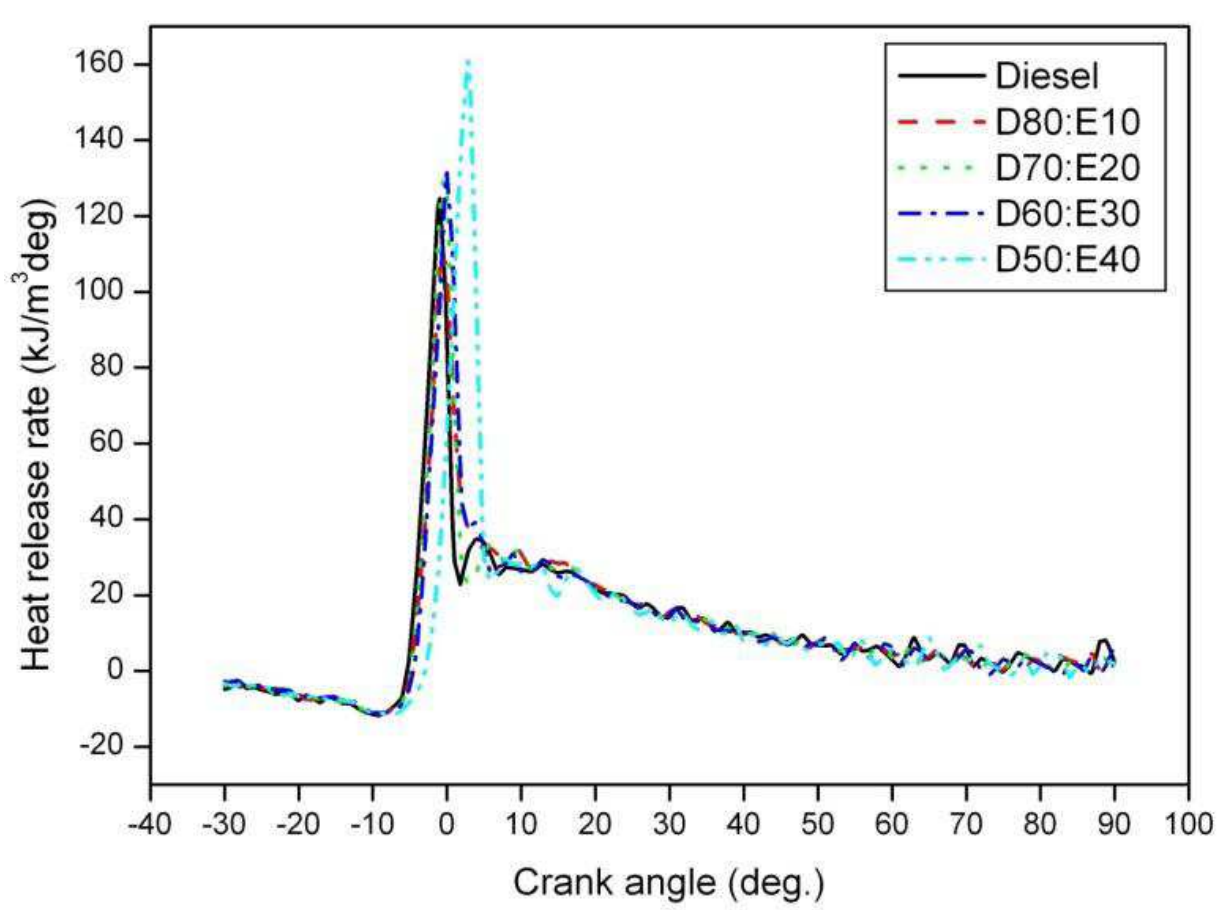

Fig. 9. Heat release rate against brake power 


\subsection{Combustion Analysis}

\subsubsection{Cylinder Pressure}

Figure 8 illustrates the variation of cylinder pressure with crank angle for different ratio of dieselethanol emulsions and diesel. It is observed that the higher percentage of ethanol blends provide maximum cylinder pressure compared to that of diesel fuel. At maximum load, the maximum cylinder pressure of diesel engine with D50E40 blend is 74.9 bar whereas it is 68.8 bar for diesel fuel.

\subsubsection{Heat Release Rate}

The heat release rate for various concentrations of emulsified fuels and diesel is shown in Fig. 9. Among the blends, the blend D50E40 shows the maximum heat release rate than diesel fuel. The higher heat release rate is recorded as $162.1 \mathrm{kj} / \mathrm{m}^{3} \mathrm{deg}$ for D50 E40 blend whereas it is $121.2 \mathrm{kj} / \mathrm{m}^{3}$ deg for diesel at full load condition.

\section{DISCUSSION}

Fuel saving and exhaust emissions reduction are the key concern of this study. As per the results, lower specific fuel consumption and higher brake thermal efficiency are mostly due to more oxygen content, reduction of energy content, lower calorific value of the blended fuel. Exhaust emission like smoke is less due to, less carbon atoms, lack of aromatics compounds, more oxygen content, better atomization and mixing of the emulsified fuel. $\mathrm{HC}$ and $\mathrm{NO}_{\mathrm{x}}$ emissions are increased by the fact that oxygen-rich ethanol concentration in the blend and lower cetane number of the blended fuel. Higher heat release rate and higher cylinder pressue are mainly due to the amount of fuel accumulated in the delay period, combustion rate in the initial stages of premixed combustion, complete combustion of the air-fuel mixture and lower cetane number of emulsified fuel.

\section{CONCLUSION}

A four-stroke single cylinder naturally aspirated direct injection diesel engine was used to study the performance, emission and combustion characteristics of diesel-ethanol-surfactant (Benzal Konium Chloride) blends and compared with those of diesel fuel. The following conclusions can be obtained as follows:
- The D50 E40 blend gives the best performance of increase in brake thermal efficiency and decrease in brake specific fuel consumption

- Hydrocarbon (HC) emission of blended fuel (D50E40) shows higher emission as compared to diesel. At full load condition, $\mathrm{HC}$ emission of D50E40, D60E30, D70E20, D80E10 and diesel is found to be $63,47,38.2,39.1$ and $39 \mathrm{ppm}$ respectively

- The oxides of nitrogen $\left(\mathrm{NO}_{\mathrm{X}}\right)$ emission is higher for higher concentration of ethanol (40\%) in the blend

- The smoke density emission of the blend D50E40 is lower than that of diesel fuel

- The $\mathrm{CO}_{2}$ emission is higher for D50E40 blend compared to diesel fuel

- The cylinder pressure and heat release rate of D50 E40 emulsified fuel are higher than other blended fuel and diesel at full load

\section{ACKNOWLEDGMENT}

We thank the management of Ganapathy Chettiar College of Engineering and Technology, Paramakudi, Tamilnadu, India for providing the necessary experimental setup to perform this research work.

\section{REFERENCES}

Ashok, M.P., 2011. Identification of best additive using the selected ratio of ethanol-diese-based emulsified fuel. Int. J. Sustain. Energy, 31: 203-212. DOI: 10.1080/1478646X.2011.556736

Cahyono, B. and R.A. Bakar, 2011. Effect of ethanol addition in the combustion process during warm-ups and half open throttle on port injection gasoline engine. Am. J. Eng. Applied Sci., 4: 66-69 DOI: 10.3844/ajeassp.2011.66.69

Chockalingam, S.R., A. Sambandam, S. Subramanian and S. Ganapathy, 2010. Performance analysis of 1,4 dioxane-ethanol-diesel blends on diesel engines with and without thermal barrier coating. Thermal. Sci., 14: 979-988. DOI: 10.2298/TSCI1004979S

Jimenez, E.T., M.S. Jerman, A. Gregorc, I. Lisec and M.P. Dorado et al., 2011. Physical and chemical properties of ethanol-diesel fuel blends. Fuel, 90: 795-802. DOI: 10.1016/j.fuel.2010.09.045

Lei, J., L. Shen, Y. Bi and H. Chen, 2012. A novel emulsifier for ethanol-diesel blends and its effect on performance and emissions of diesel engine. Fuel, 93: 305-311. DOI: 10.1016/j.fuel.2011.06.013 
Lincy, R. and K.H. Wang, 2003. The fuel Properties of three phases emulsion as an alternative fuel for diesel engine. Fuel, 82: 1367-1375. DOI: 10.1016/S0016-2361(03)00021-8

Muralidharan, K. and P. Govindarajan, 2011. The effects of bio-fuel blends and fuel injection pressure on diesel engine emission for sustainable environment. Am. J. Environ. Sci., 7:377-382. DOI: 10.3844/ajessp.2011.377.382

Prabhu, L., S. Sathish kumar, M. Prabhakar and K. Rajan, 2013. Combustion, performance and emission characteristics of diesel engine with neem oil methyl ester and its diesel blends. Am. J. Applied Sci., 10: 810-818. DOI: 10.3844/ajassp.2013.810.818
Rajkumar, K. and P. Govindarajan, 2011. Impact of oxygen enriched air intake on the exhaust of a single cylinder diesel engine. Am. J. Applied Sci., 7: 136140. DOI: 10.3844/ajessp.2011.136.140

Sayin, C., 2010. Engine performance and ehaust gas emissions of methanol and ethanol-diesel blends. Fuel, 89: 3410-3415. DOI: 10.1016/j.fuel.2010.02.017 